\title{
PENGARUH CELEBRITY ENDORSER, ASOSIASI MEREK, KEPERIBADAIAN MEREK DAN KARAKTERISTIK PRODUK TERHADAP INTENS PEMBELIAN PRODUK KOPI DI JAKARTA BARAT
}

\author{
Hannes Widjaya, Chandra Saputra, Kurniati W Andani \\ Fakultas Ekonomi Universitas Tarumanagara \\ Email: hanneswidjaya@gmail.com
}

\begin{abstract}
Perceptions of the product can be built the company by providing information on the product, and the best way in the delivery of information is the promotion. One way of promotion of the most rising concern of many companies in introducing their products is through advertising. The purpose of this study was to determine the influence of celebrity endorsers, brand association, brand personalities and characteristics of the product to the intention of purchase. Sample selection methods by using a simple random sampling. Data obtained through questionnaires of 125 respondents in West Jakarta as a sample of researchers. Analyses were performed using multiple regression analysis. The results showed that of the four independent variables, celebrity endorser, brand association, brand personality and product characteristics significantly influence purchase intention simultaneously, while celebrity endorser does not significantly affect the intense partial purchase.
\end{abstract}

Keywords: celebrity endorser, brand association, brand personalities, characteristics of the product purchase intentions

\section{PENDAHULUAN}

Era globalisasi persaingan bisnis semakin dinamis, kompleks dan serba tidak pasti. Persaingan tersebut terlihat jelas dengan Begitu beragam dan banyaknya produk yang ditawarkan berbagai perusahaan namun semakin sedikitnya konsumen yang membeli, serta semakin jelinya konsumen dalam menentukan produk yang akan mereka beli. Hal inilah yang menyebabkan berbagai Perusahaan berlomba-lomba untuk menciptakan presepsi baik mengenai produk yang mereka tawarkan. Fandy (2007) menjelaskan, karena pada dasarnya persepsi pelanggan mengenai produk lebih penting dibandingkan kenyataan yang melekat pada produk itu sendiri. ditambah lagi konsumen lebih memperhatikan merek ketimbang produknya saat melakukan pembelian.

Persepsi mengenai produk dapat dibangun perusahaan dengan memberikan informasi mengenai produk, dan cara terbaik dalam penyampaian informasi adalah dengan promosi. Salah satu cara promosi yang paling menaik perhatian banyak perusahaan dalam memperkenalkan produk mereka adalah melalui iklan. Ada beberapa tujuan khusus dari iklan diantaranya untuk membentuk kesadaran akan suatu produk atau merek baru, menginformasikan fitur dan keunggulan produk atau merek pada kemasan, membentuk persepsi tertentu akan produk atau merek, membentuk selera akan produk atau merek ataupun membujuk para konsumen untuk membeli produk yang diiklankan (shimp, 2003).

Iklan yang dapat berhasil dalam penyampaiannya haruslah suatu iklan yang menarik, persuasif dan terpercaya. Untuk menciptakan hal tersebut, banyak produsen yang menggunakan selebriti endorser yang terpercaya dan disegani dalam menyampaikan kampanye iklan produknya Kotler (2008). Bintang iklan disini merupakan aktor, 
penghibur, atau atlet yang dikenal masyarakat karena prestasinnya dan berperan sebagai orang yang berbicara tentang produk, yang pada akhirnya dapat mempengaruhi sikap dan perilaku konsumen yang menunjuk pada produk yang didukungnya (Shimp, 2003).

Selebriti endorser saja tidak cukup dalam menciptakan iklan menarik dan persuasif. Prayitno (2003) selain dengan selebriti endorser yang terpercaya dan disukai konsumen, produsen juga perlu menciptakan kekuatan merek di benak konsumen melalui penyampaian kepribadian merek, karakteristik produk dan asosiasi merek yang dikemas dengan baik di dalam iklan. dengan cara ini, merek diharapkan akan menjadi sangat kuat di dalam benak konsumen, sehingga merek dapat membangun hubungan emosional dan memberikan kemudahan bagi para konsumen untuk mengidentifikasi perbedaan dan keunggulan produk yang diiklankan.

Penelitian sebelumnya yang hampir serupa dengan fenomena diatas adalah penelitian yang dilakukan oleh Nurani dan Haryanto (2010). Hasil penelitian tersebut menunjukkan bahwa asosiasi merek dan karakteristik produk berpengaruh signifikan terhadap niat untuk membeli Kuku Bima Ener-G Rosa, sedangkan endorser selebriti dan kepribadian merek tidak berpengaruh signifikan terhadap niat untuk membeli Kuku Bima Ener-G Rosa. Perbedaan penelitian tersebut dengan fenomena ini terletak pada produk dan pengemasan iklannya, dimana produk TOP kopi merupakan Produk baru dan Iklannya menggunakan pengemasan lebih menonjolkan kepribadian merek dan selebriti endorser.

Setelah mengamati dan mempelajari fenomena tersebut, terdapat sebuah permasalahan yang menarik, yaitu apakah selebriti endorser, asosiasi merek, kepribadian merek dan karakteristik produk dapat benar-benar berpengaruh positif dalam menciptakan intensi penjualan. Oleh karena itu judul penelitian ini berfokus pada "Pengaruh Selebriti Endorser, Asosiasi Merek, Kepribadian Merek dan Karakteristik Produk Terhadap Intensi Pembelian Produk Pada Iklan TOP Kopi Versi Iwan Fals"

Berdasarkan latar belakang yang telah diuraikan, maka dapat dirumuskan lima persoalan penelitian, yaitu: (1) Apakah selebriti endorser dalam iklan TOP kopi memiliki pengaruh terhadap intensi pembelian produk; (2) Apakah asosiasi merek dalam iklan TOP kopi memiliki pengaruh terhadap intensi pembelian produk; (3) Apakah kepribadian merek dalam iklan TOP kopi memiliki pengaruh terhadap intensi pembelian produk; (4) Apakah karakteristik produk dalam iklan TOP kopi memiliki pengaruh terhadap intensi pembelian produk; (5) Apakah selebriti endorser, asosiasi merek, kepribadian merek, dan karakteristik produk dalam iklan TOP kopi memiliki pengaruh terhadap intensi pembelian produk?

Tujuan dalam penelitian ini adalah: (1) untuk mengetahui pengaruh selebriti endorser dalam iklan TOP kopi terhadap intensi pembelian produk; (2) untuk mengetahui pengaruh asosiasi merek dalam iklan TOP kopi terhadap intensi pembelian produk; (3) untuk mengetahui pengaruh kepribadian merek dalam iklan TOP kopi terhadap intensi pembelian produk; (4) untuk mengetahui pengaruh karakteristik produk dalam iklan TOP kopi terhadap intensi pembelian produk; (5) untuk mengetahui pengaruh selebriti endorser, asosiasi merek, kepribadian merek, dan karakteristik produk dalam iklan TOP kopi terhadap intensi pembelian produk.

\section{KAJIAN TEORI}

Terence Shimp (2003) menggolongkan dua atribut dalam memfasilitasi efektivitas komunikasi selebriti endorser. Secara spesifik Shimp mengatakan bahwa 2 dimensi 
selebriti endorser terdiri dari Credibility dan Attractiveness, dimana credibility terdiri dari Trustworthiness dan Expertise. Sedangkan Attractiveness terdiri dari liking, familiarity dan similarity.

Pengukuran asosiasi merek dapat dilakukan dengan lima pendekatan dari Durianto dan Sitinjak (2001), yaitu: Asosiasi dari atribut produk (Product attributes), Asosiasi atribut produk tak berwujud (Intangibles Attributes), Asosiasi manfaat bagi pelanggan (Customer's benefit), Asosiasi gaya hidup/kepribadian (Life Style/personality) dan Asosiasi dari sisi pesaing (Competition).

Membentukan kepribadian merek yang jelas merupakan salah satu faktor penting dalam proses membangun merek yang kuat. kepribadian merek yang dibuat secara konsisten akan sulit di contoh oleh pesaing." Agar hal tersebut dapat terjadi, maka dalam pembentukan kepribadianmerek harus memperhatikan dimensi - dimensnya. Dalam penelitian yang dilakukan Aaker (1997) mengenai 5 dimensi dari kepribadian merek, yaitu: Sincerity (ketulusan), Excitement (ketertarikan), Competence (kemampuan), Sophistication (keduniawian), Ruggedness (ketangguhan).

Peter dan Olson (2002) mendepenelitiankan tujuh karakteristik yang harus dimiliki oleh sebuah produk agar, sukses dalam menjaring pelanggan. Ketujuh faktor itu antara lain. Kompatibilitas (compatibility), Kemampuan Untuk Diuji Coba (trialability), Kemampuan Untuk Diteliti (observability), Kecepatan (speed), Kesederhanaan (simplicity), Manfaat relatif (relative advantage), Simbolisme produk (product simbolisme)

Menurut Ajzen (2005), Intensi memiliki korelasi yang tinggi dengan perilaku, oleh karena itu dapat digunakan untuk meramalkan perilaku. Hal ini dapat juga berlaku pada perilaku membeli. Dengan mengukur intensi membeli individu, dapat diramalkan bahwa individu tersebut akan melakukan perilaku membeli. Terdapat 3 aspek intensi membeli yang berasal dari aspek-aspek intensi berperilaku dari Ajzen (2005), yaitu sebagai berikut: Sikap Konsumen Terhadap Perilaku Membeli, Norma Subjektif Terhadap Perilaku Membeli, Kontrol Perilaku Terhadap Perilaku Membeli.

Menurut Suyanto (2005) Saat ini kebanyakan perusahaan menggunakan selebriti dibanding orang biasa untuk mengiklankan produknya karena selebriti memiliki atribut kesohoran, kecantikan, keberanian, prestasi, jiwa olahraga (athleticisme), keanggunan, kekuasaan/kekuatan, dan daya tarik seksualnya sehingga sering mewakili daya tarik yang diinginkan perusahaan untuk mengiklankan produknya dan dijadikan pemikat yang ampuh bagi calon konsumen. Engel, Black Well \& Miniard (1990) menyatakan bahwa Endorser yaitu orang atau karakter yang muncul dalam iklan untuk mengkomunikasikan produk perusahaan baik itu selebritis, tokoh masyarakat, publik figure atau bahkan orang biasa yang dapat mempengaruhi pikiran konsumen sebagai preferensi dalam melakukan keputusan pembelian.

Aaker (1991) berpendapat Assosiasi mempunyai tingkatan kekuatan, yang dapat menciptakan citra merek dan menjadi dasar untuk keputusan pembelian dan loyalitas merek. Lebih lanjurnya juga Aaker menyatakan bahwa (1992) Asosiasi merek adalah aset yang dapat meningkatkan nilai, dan sebagai dasar penting untuk melakukan pembedaan, keunggulan kompetitif, mempengaruhi keputusan pembelian, mendorong perasaan dan sikap positif dan peningkatan pembelian.

Anoraga (2000) menyatakan bahwa dengan pendekatan menarik yang dilakukan oleh suatu perusahaan, maka konsumen secara sengaja dipengaruhi untuk mulai mengevaluasi keuntungan - keuntungan yang dapat diperoleh jika membeli produk yang ditawarkan dan 
dengan mudah konsumen menemukan produk yang sesuai dengan kepribadiannya/yang diinginkan dan pada akhirnya akan menciptakan suatu proses pengambilan keputusan yang dilakukan oleh konsumen yang bersangkutan sebelum mengadakan pembelian atas produk tersebut.

Engel, et al (1994) menyatakan bahwa atribut produk adalah karakteristik dari suatu produk yang berfungsi sebagai atribut evaluatif selama pengambilan keputusan. Selain itu Kottler dan Keller (2006) juga berpendapat bahwa Setiap produk memiliki karakteristik yang berbeda-beda, dan setiap produsen selalu berusaha menciptakan produk yang memiliki karakteristik tersendiri sehingga konsumen memiliki persepsi khusus terhadap produk tersebut.

Pengaruh Selebriti Endorser Terhadap Intensi Pembelian. Menurut Suyanto (2005) Saat ini kebanyakan perusahaan menggunakan selebriti dibanding orang biasa untuk mengiklankan produknya karena selebriti memiliki atribut kesohoran, kecantikan, keberanian, prestasi, jiwa olahraga (athleticisme), keanggunan, kekuasaan/kekuatan, dan daya tarik seksualnya sehingga sering mewakili daya tarik yang diinginkan perusahaan untuk mengiklankan produknya dan dijadikan pemikat yang ampuh bagi calon konsumen. Engel, Black Well \& Miniard (1990) menyatakan bahwa Endorser yaitu orang atau karakter yang muncul dalam iklan untuk mengkomunikasikan produk perusahaan baik itu selebritis, tokoh masyarakat, publik figure atau bahkan orang biasa yang dapat mempengaruhi pikiran konsumen sebagai preferensi dalam melakukan keputusan pembelian.

Shimp (2003) Menyatakan bahwa Penggunaan komunikator celebrity endorser yang memiliki karakteristik akan dapat mempengaruhi sikap (attitudes) atau tanggapan konsumen yang positif terhadap produk tersebut, sehingga konsumen akan mempertimbangkannya dalam proses pembelian dan diharapkan secara langsung mempengaruhi perilaku melalui alam tak sadar mereka. Dengan demikian konsumen dipengaruhi untuk membeli tanpa ada paksaan. Setelah terpengaruh secara suka rela, merasa ingin dan senang kepada produk, maka apabila konsumen mempunyai kemampuan untuk membeli pada akhirnya akan melakukan pembelian terhadap produk yang diinginkan di masa yang akan datang.

Pengaruh Asosiasi Merek Terhadap Intensi Pembelian. Aaker (1991) berpendapat Assosiasi mempunyai tingkatan kekuatan, yang dapat menciptakan citra merek dan menjadi dasar untuk keputusan pembelian dan loyalitas merek. Lebih lanjurnya juga Aaker menyatakan bahwa (1992) Asosiasi merek adalah aset yang dapat meningkatkan nilai, dan sebagai dasar penting untuk melakukan pembedaan, keunggulan kompetitif, mempengaruhi keputusan pembelian, mendorong perasaan dan sikap positif dan peningkatan pembelian.

Menurut Low dan Lamb Jr (2000) Bagi konsumen, asosiasi merek dapat membantu proses, mengorganisir, dan mendapatkan kembali informasi dalam ingatan dan untuk membantu pegambilan keputusan pembelian. Sedangkan Washburn mengatakan bahwa Konsumen dapat mengembangkan keragaman asosiasi nama merek dan kemudian mengelompokkan dalam co-branding produk, memproses informasi, membedakan merek, membantu pilihan pembelian yang rasional, menciptakan sikap dan perasaan positif, serta memberikan dasar menciptakan rasa kesesuaian antara nama merek dan produk baru. 
Pengaruh Kepribadian Merek Terhadap Intensi Pembelian. Anoraga (2000) menyatakan bahwa dengan pendekatan menarik yang dilakukan oleh suatu perusahaan, maka konsumen secara sengaja dipengaruhi untuk mulai mengevaluasi keuntungan keuntungan yang dapat diperoleh jika membeli produk yang ditawarkan dan dengan mudah konsumen menemukan produk yang sesuai dengan kepribadiannya/yang diinginkan dan pada akhirnya akan menciptakan suatu proses pengambilan keputusan yang dilakukan oleh konsumen yang bersangkutan sebelum mengadakan pembelian atas produk tersebut.

Hubungan emosional yang terbentuk oleh kepribadian merek akan meningkatkan preferensi konsumen terhadap sebuah merek dan membuka peluang konsumen untuk loyal (temporal, 2001 dalam Chasanah, 2003). sedangkan Menurut Bauer Mader dan Keller (2001) sebuah kepribadian merek dapat membantu proses komunikasi pada konsumen dikarenakan memberi kemudahan konsumen dalam mengidentifikasi merek.

Pengaruh Karakteristik Produk Terhadap Intensi Pembelian. Engel, et al (1994) menyatakan bahwa atribut produk adalah karakteristik dari suatu produk yang berfungsi sebagai atribut evaluatif selama pengambilan keputusan. Selain itu Kottler dan Keller (2006) juga berpendapat bahwa Setiap produk memiliki karakteristik yang berbeda-beda, dan setiap produsen selalu berusaha menciptakan produk yang memiliki karakteristik tersendiri sehingga konsumen memiliki persepsi khusus terhadap produk tersebut.

Menurut Kotler \& Keller (2006) Karakteristik produk adalah ciri - ciri khusus atau spesifik dari produk yang berbeda dari pesaing dan dapat ditawarkan ke pasar untuk memenuhi keinginan atau kebutuhan pelanggan. Sedangkan Ryerson dalam Solomon (2007) mengemukakan bahwa faktor karakteristik produk merupakan faktor yang penting dalam merebut antusiasme konsumen. Karakteristik suatu produk merupakan suatu modal atau atribut penting, sejauh mana produk tersebut mampu memberikan keuntungan untuk memenuhi tujuan yang lebih besar.

Kerangka Pemikiran. Teori Behavior merupakan teori yang dicetuskan oleh Gaga dan Berliner tentang perubahan tingkah laku sebagai hasil dari pengalaman. Kemudian teori ini berkembang menjadi aliran psikologi yang berpengaruh terhadap perkembangan teori pendidikan, pemasaran, komunikasi yang dikenal sebagai aliran behavioristik. Aliran ini menekankan pada terbentuknya perilaku yang tampak sebagai hasil belajar.

Teori behavior dengan model hubungan stimulus respon, mendudukan orang yang belajar sebagai mahluk yang pasif. Respon atau perilaku tertentu dengan menggunakan metode pelatihan atau pembinaan semata. Behaviorisme tidak mau mempersoalkan apakah manusia baik atau jelek. Teori ini memandang manusia sebagai mahluk yang reaktif yang memberi respon terhadap lingkungan. Pengalaman dan pemeliharaan akan membentuk perilaku mereka.

Dalam hubungan dengan tesis ini penulis mencoba mencari kerangka pemikiran dari teori-teori dasar sebelum sampai pada pokok permasalahan di bidang komunikasi pemasaran. Perkembangan teori behavior peneliti mencoba mengambil runtutannya dari teori S-R dimana teori ini menunjukkan sebagai proses aksi (stimulus) dan reaksi (respon) yang sangat sederhana. Teori ini mengasumsikan bahwa kata-kata verbal (lisan-tulisan), isyarat-isyarat nonverbal, gambar-gambar, dan tindakan-tindakan tertentu akan merangsang orang lain untuk memberikan respon dengan cara tertentu.

Dalam proses perpindahan informasi ada dua kemungkinan respon yang akan terjadi setelah stimuli diberikan oleh komunikator, yaitu reaksi negatif atau positif. Reaksi positif 
terjadi apabila komunikan menerima stimuli dari komunikator dan memberikan reaksi seperti apa yang diharapkan oleh sang komunikator dalam hal ini adalah iklan Top kopi versi Iwan Fals. Teori S-R mengabaikan komunikasi sebagai suatu proses, khususnya yang berkenaan dengan faktor manusia. Secara implisit ada saumsi dalam teori S-R ini bahwa perilaku (respon) manusia dapat diramalkan. Manusia berperilaku karena kekuatan dari luar (stimulus), bukan berdasarkan kehendak, keingingan atau kemauan bebasnya.

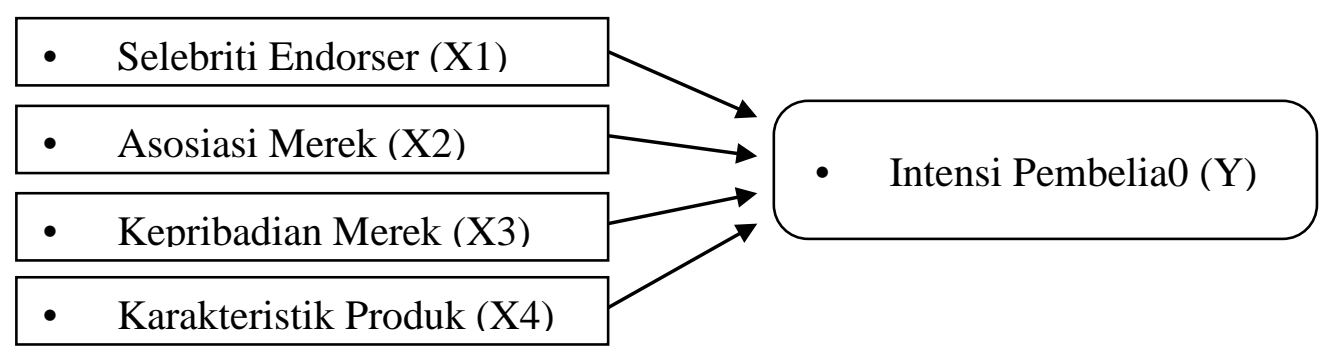

\section{Hipotesis}

Gambar 1. Rerangka Pemikiran

Hipotesis penelitian dalam penelitian ini adalah:

$\mathrm{H}_{1}=$ Selebriti Endorser memiliki pengaruh terhadap Intensi pembelian produk.

$\mathrm{H}_{2}=$ Asosiasi Merek memiliki pengaruh terhadap intensi pembelian produk.

$\mathrm{H}_{3}=$ Kepribadian Merek memiliki pengaruh terhadap intensi pembelian produk.

$\mathrm{H}_{4}=$ Karakteristik Produk memiliki pengaruh terhadap intensi pembelian produk.

$\mathrm{H}_{5}=$ Selebrity Endorser, Asosiasi Merek, Kepribadian Merek, dan Karakteristik produk memiliki pengaruh terhadap intensi pembelian produk.

\section{METODE}

Populasi, Sampling dan Metode Penarikan Sampel. Menurut Maholtra (2004), populasi adalah gabungan seluruh elemen, yang memiliki serangkaian karakteristik serupa, yang mencakup semesta untuk kepentingan masalah riset pemasaran. Sugiyono (2003) berpendapat bahwa populasi adalah wilayah generalisasi yang terdiri atas objek/subyek yang mempunyai kualitas dan karakteristik tertentu yang ditetapkan oleh peneliti untuk dipelajari dan kemudian ditarik kesimpulannya. Populasi pada penelitian ini adalah masyarakat yang tinggal Jakarta, khususnya Jakarta Barat yang pernah melihat iklan TOP kopi.

Teknik sampling secara kluster (cluster sampling) Ada kalanya peneliti tidak tahu persis karakteristik populasi yang ingin dijadikan subjek penelitian karena populasi tersebar di wilayah yang amat luas. Untuk itu peneliti hanya dapat menentukan sampel wilayah, berupa kelompok klaster yang ditentukan secara bertahap. Teknik pengambilan sample semacam ini disebut cluster sampling atau multi-stage sampling. Oleh karenanya agar tidak sangat subjektif, peneliti harus punya latar belakang pengetahuan tertentu mengenai sampel dimaksud (tentu juga populasinya) agar benar-benar bisa mendapatkan sampel yang sesuai dengan persyaratan atau tujuan penelitian (Maholtra, 2004). Responden yang akan dijakdikan sampel adalah masyarakat yang tinggal di daerah Jakarta Barat karena dari data BPS tahun 2014 jumlah penduduk dari lima wilayah yang ada di 
DKI Jakarta, Jakarta barat yang paling terbanyak dengan total penduduk 8,1 juta jiwa dari 27,8 juta jiwa.

Pengumpulan Data. Metode pengumpulan data yang akan dilakukan adalah dengan metode kuesioner terstruktur terbuka. Metode kuesioner terstruktur terbuka adalah kuesioner dengan pertanyaan-pertanyaan yang telah ditetapkan dan distandarisasikan sehingga pertanyaan-pertanyaan diajukan dengan susunan kata-kata dan urutan yang sama kepada semua responden ketika mengumpulkan data (Churchill, 2005). Data yang diperoleh adalah data primer. Data primer adalah data yang dikumpulkan dan diperoleh sendiri oleh suatu organisasi atau perseorangan langsung dari objeknya yaitu melalui survei (singarimbun, 1991).

Kuesioner penelitian akan mengumpulkan sampel yang berjumlah sesuai dengan aturan pengumpulan data primer menurut Supranto (2003), bahwa umumnya riset bidang sosial seperti ekonomi, sosiologi, psikologi, manajemen, perbankan, pemasaran. Diperoleh data primer dengan sampel (n > 30)." Berdasarkan referensi tersebut maka jumlah sampel yang dipilih sebanyak 125 orang responden.

Teknik Analisis Data. Teknik pengolahan dan analisis data yang digunakan pada penelitian ini adalah teknik analisis regresi berganda, dengan penyelesaian menggunakan program SPSS. Teknik analisis regresi berganda digunakan untuk meramalkan bagaimana keadaan variable dependen (terikat) bila dua atau lebih variable independen (bebas) sebagai faktor predictor dimanipulasi. Dalam jurnal penelitian ini analisis regresi berganda digunakan untuk mengidentifikasikan pengaruh dari masing-masing faktor yaitu Iwan Fals sebagai selebriti Endorser dan Kepribadian merek produk.

Model persamaan regresi berganda yang digunakan dalam penelitian ini adalah sebagai berikut.

$$
\mathrm{Y}=\beta 0+\beta 1 \mathrm{X} 1+\beta 2 \mathrm{X} 2+\beta 3 \mathrm{X} 3+\beta 4 \mathrm{X} 4+\varepsilon
$$

Dimana $=\mathrm{Y}=$ Merupakan variable Dependen. $\mathrm{Y}$ didefinisikan sebagai Intensi membeli $\beta 0=$ Konstanta; $\beta 1$ - 2 = Koefisien regresi; X1 = Selebriti Endorser; X2 = Asosiasi Merek; X3 = Kepribadian Merek; X4 = Karakteristik Produk; $\boldsymbol{\varepsilon}=$ Residual

Uji asumsi klasik yang digunakan dalam penelitian ini adalah : Heteroskedastitas dapat terjadi bila untuk setiap nilai variabel independen terdapat beberapa skor variabel dependen dengan variasi yang berbeda. Model regresi yang baik seharusnya tidak terjadi heteroskedastisitas. Heteroskedastisitas dapat dideteksi dengan grafik scatterplots melalui pengujian SPSS. Normalitas dapat terjadi bila nilai variabel independen dan variabel dependen berdistribusi normal atau mendekati normal. Model regresi yang baik seharusnya distribusi datanya normal atau mendekati normal. Uji multikolinieritas digunakan untuk menguji hubungan antara variabel independen memiliki korelasi yang signifikan atau sempuma mendekati 1 atau -1 (Aritonang, 2009).

Uji-t dilakukan untuk menguji koefisien regresi secara parsial, yaitu untuk menguji apakah terdapat pengaruh yang signifikan dari suatu variabel independen terhadap variabel dependen jika variabel independen yang lain dianggap konstan. Uji-F dilakukan untuk menguji koefisien regresi secara bersama-sama, yaitu untuk menguji apakah terdapat pengaruh yang signifikan dari semua variabel independen secara bersama-sama terhadap variabel dependen. Uji $R$-square memiliki tujuan untuk mengukur seberapa besarnya proporsi atau persentase dari jumlah variasi dari variabel dependen atau untuk mengukur 
sumbangan dari variabel independen terhadap variabel dependen. Nilai $\mathrm{R}^{2}$ yang kecil berarti kemampuan variabel-variabel independen dalam menjelaskan variasi variabel dependen amat terbatas, sedangkan nilai yang besar (mendekati 1) berarti variabel-variabel independen memberikan hampir semua informasi yang dibutuhkan untuk memprediksi variasi variabel dependen.

\section{HASIL DAN PEMBAHASAN}

Pendeteksian ada atau tidaknya nomalitas dapat dilihat pada tampilan grafik normal P-Plot of regression standardized. Jika data menyebar di sekitar garis diagonal dan mengikuti arah garis diagonal, maka model regresi memenuhi asumsi normalitas.Jika data menyebar jauh dari garis diagonal dan tidak mengikuti arah garis diagonal, maka model regresi tidak memenuhi asumsi normalitas.

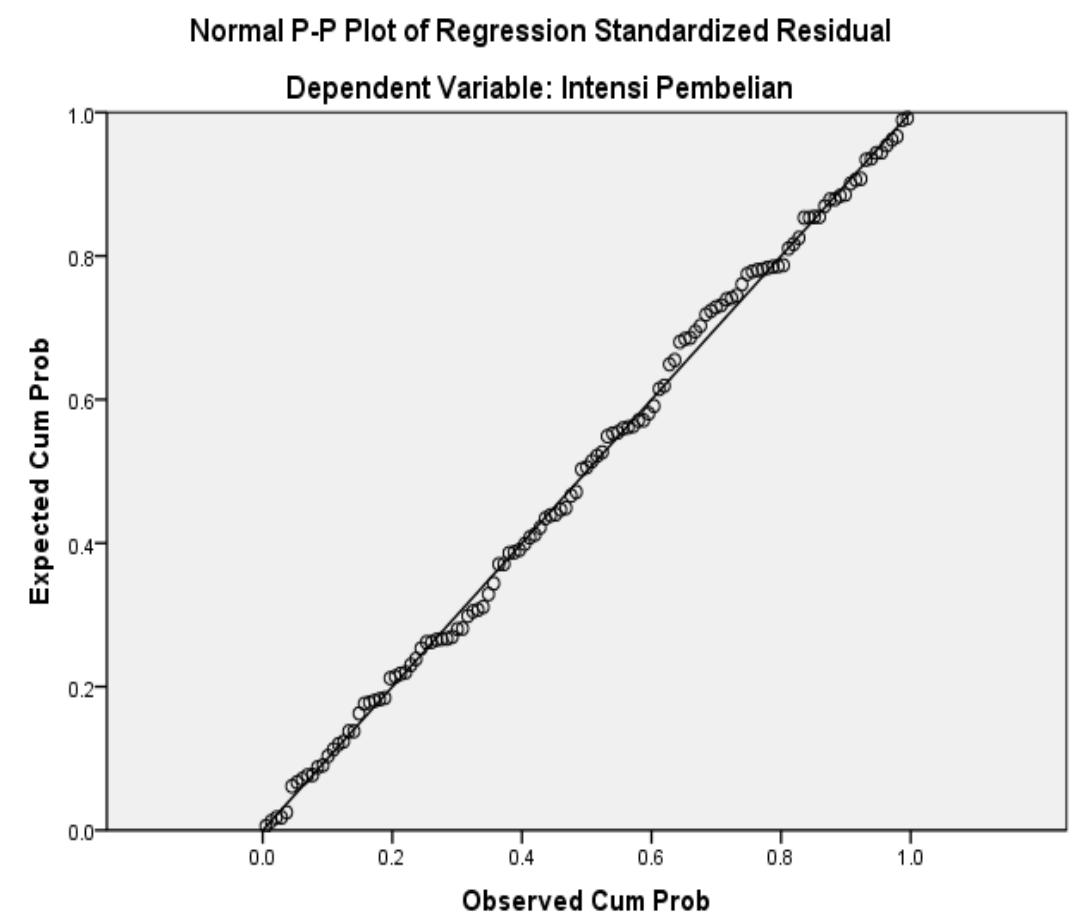

Gambar 1. Uji Normalitas

Gambar 1 menunjukkan bahwa data terdistribusi normal karena titik-titik data menyebar di sekitar garis diagonal dan mengikuti arah garis diagonal sehingga model regresi memenuhi asumsi normalitas. Pendeteksian ada atau tidaknya multikolinearitas didasarkan ada besamya variance inflation factor (VIF), yaitu suatu estimasi besarnya multikolinearitas yang dapat menungkatkan varian pada suatu koefisien estimasi sebuah variabel penjelas. Jika nilai VIF dalam suatu model regresi tidak lebih besar dari 10, maka tidak terdapat multikolinearitas. 
Tabel 1. Uji Multikolinearitas

\begin{tabular}{|ll|l|}
\hline Model & VIF \\
\hline $1 \quad$ (Constant) & \\
& selebriti endorser & 1.888 \\
& asosiasi merek & 3.770 \\
& kepribadian merek & 2.975 \\
& karakteristik & 1.944 \\
& produk & \\
\hline \multicolumn{2}{|l|}{ Dependent Variable: Intensi } & Pembelian
\end{tabular}

Tabel 1 menunjukkan bahwa nilai VIF keempat variabel tidak lebih besar dari 10 sehingga tidak terdapat multikolinearitas.

Model regresi yang baik seharusnya tidak terdapat heteroskedastisitas. Pendeteksian ada atau tidaknya heteroskedastisitas dapat dilihat pada gambar scatterplot. Jika titik-titik data menyebar diatas dan dibawah angka 0 pada sumbu $\mathrm{Y}$, maka tidak terdapat heteroskedastisitas.

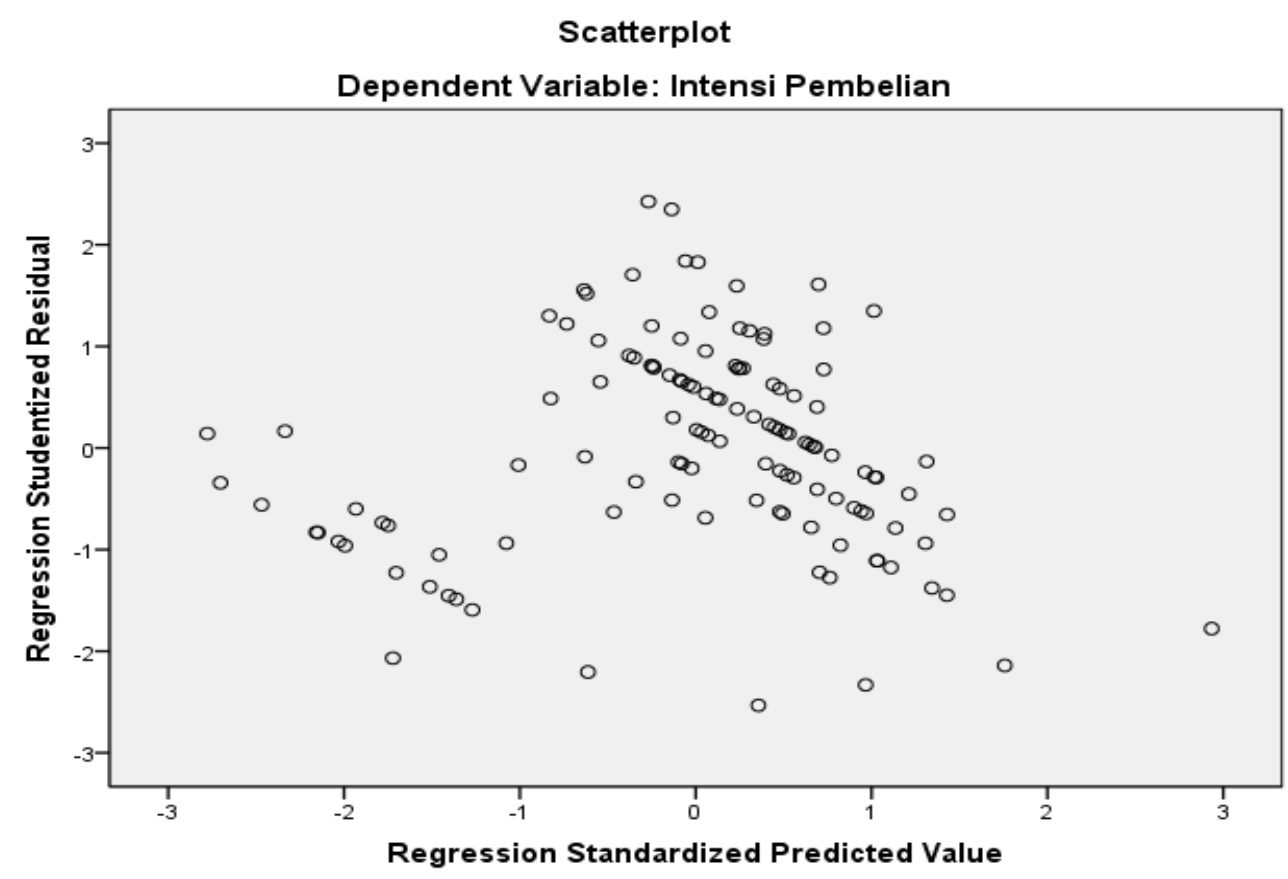

Gambar 2. Uji Heteroskedastisitas

Gambar 2 menunjukkan bahwa titik-titik data menyebar diatas dan di bawah angka 0 pada sumbu Y, maka dapat disimpulkan bahwa tidak terdapat heteroskedastisitas. Analisi regresi digunakan untuk mengetahui pengaruh variabel indenpenden (X) terhadap perubahan variabel dependen (Y). Dalam hal ini variabel independen adalah selebriti 
endorser (X1), asosiasi merek (X2), kepribadian produk (X3), dan karakteristik produk (X4), sedangkan variabel dependennya adalah Intensi Pembelian (Y). Persamaan regresinya sebagai berikut:

$$
\mathrm{Y}=3.082-0.042 \mathrm{X} 1-0.182 \mathrm{X} 2+0.163 \mathrm{X} 3+0,255 \mathrm{X} 4
$$

Penjelasan dari persamaan diatas sebagai berikut: (1) Jika selebriti endorser (X1), asosiasi merek (X2), kepribadian merek (X3), dan karakteristik produk (X4) masing-masingnya = 0 maka Intensi pembelian $(\mathrm{Y})=0,184$; (2) Jika terjadi perubahan selebriti endorser (X1) sebesar 1 saruan dan ketiga variabel lainya konstan, maka intensi pembelian (Y) akan mengalami perubahan sebesar 0,042 saruan; (3) Jika terjadi perubahan asosiasi merek (X2) sebesar 1 saruan dan ketiga variabel lainya konstan, maka intensi pembelian (Y) akan mengalami perubahan sebesar 0,182 satuan; (4) Jika terjadi perubahan kepribadian merek (X3) sebesar 1 saruan dan ketiga variabel lainya konstan, maka intensi pembelian (Y) akan mengalami perubahan sebesar 0,163 saruan; (5) Jika terjadi perubahan karakteristik produk (X4) sebesar 1 saruan dan ketiga variabel lainya konstan, maka intensi pembelian (Y) akan mengalami perubahan sebesar 0,255 saruan.

Hasil uji-t antara XI (selebriti endorser) dengan Y (intensi pembelian) menunjukkan tingkat signifikasi 0,210. Hal ini berarti selebriti endorser tidak mempengaruhi intensi pembelian karena angka probabilitas/ signifikasi lebih besar dari $\alpha=5 \%$. Jadi, dapat disimpulkan bahwa H0 tidak ditolak dan Ha ditolak. Dan juga dari hasil t hitung lebih kecil dari t tabel $(-1,261<1,9797)$, maka Ha ditolak, artinya selebriti endorser tidak mempengaruhi intensi pembelian.

Hasil uji-t antara X2 (asosiasi merek) dengan $\mathrm{Y}$ (intensi pembelian) menunjukkan tingkat signifikasi 0,002 . Hal ini berarti asosiasi merek mempengaruhi intensi pembelian karena angka probabilitas / signifikasi lebih kecil dari $\alpha=5 \%$. Jadi, dapat disimpulkan bahwa H0 ditolak dan Ha tidak ditolak. Dan juga dari hasil t hirung lebih besar dari t tabel ( -3,177 > -,9797), maka Ha tidak ditotak, artinya asosiasi merek mempengaruhi intensi pembelian.

Hasil uji-t antara X3 (kepribadian merek) dengan $\mathrm{Y}$ (intensi pembelian) menunjukkan tingkat signifikasi 0,004. Hal ini berarti kepribadian merek mempengaruhi intensi pembelian karena angka probabilitas / signifikasi lebih kecil dari $\alpha=5 \%$. Jadi, dapat disimpulkan bahwa H0 ditolak dan Ha tidak ditolak. Dan juga dari hasil t hirung lebih besar dari t tabel ( 2,896> 1,9797), maka Ha tidak ditotak, artinya kepribadian merek mempengaruhi intensi pembelian.

Hasil uji-t antara X4 (karakteristik produk) dengan $\mathrm{Y}$ (intensi pembelian) menunjukkan tingkat signifikasi 0,000 . Hal ini berarti asosiasi merek mempengaruhi intensi pembelian karena angka probabilitas / signifikasi lebih kecil dari $\alpha=5 \%$. Jadi, dapat disimpulkan bahwa H0 ditolak dan Ha tidak ditolak. Dan juga dari hasil t hitung lebih besar dari t tabel ( 7,719> 1,9797), maka Ha tidak ditotak, artinya karakteristik produk mempengaruhi intensi pembelian.

Nilai F pada tabel 4.21 dengan df $(4-1=3) ;(125-4=121)$ adalah sekitar 2,7. Karena $\mathrm{F}$ hitung lebih besar dari F dari pada F tabel $(23,339>2,7)$, maka H0 ditolak, artinya paling sedikut ada satu variabel independen yang mempengaruhi variabel intense pembelian. Dari tabel diperoleh tingkat signifikasi sebesar 0,000 dimana angka tersebut lebih kecil dari 0,05, ini berarti H0 ditotak maka dapat disimpulkan bahwa paling sedkit terdapat satu variabel independen yang mempengaruhi intensi pembelian. Dengan 
demikian uji secara parsial (uji-t) untuk menjawab hipopenelitian penelitian dapat dilakukan untuk mengetahui variabel independen mana saja yang mempengaruhi variabel kepuasan pelanggan.

\section{PENUTUP}

Simpulan. Selebriti endorser tidak mempengaruhi intensi pembelian terhadap produk TOP coffe. Hasil uji-t antara XI (selebriti endorser) dengan Y (intensi pembelian) menunjukkan tingkat signifikasi 0,210. Hal ini berarti selebriti endorser tidak mempengaruhi intensi pembelian karena angka probabilitas/ signifikasi lebih besar dari $\alpha$ $=5 \%$. Jadi, dapat disimpulkan bahwa H0 diterima dan Ha ditolak. Dimana dari hasil penelitian diperoleh hasil t hitung lebih kecil dari t tabel $(-1,261<1,9797)$, maka Ha ditolak, artinya selebriti endorser tidak mempengaruhi intensi pembelian.

Asosiasi merek mempengaruhi intensi pembelian terhadap produk TOP coffe pada warga tanjung duren di Jakarta. Hasil uji-t antara X2 (asosiasi merek) dengan $\mathrm{Y}$ (intensi pembelian) menunjukkan tingkat signifikasi 0,002. Hal ini berarti asosiasi merek mempengaruhi intensi pembelian karena angka probabilitas / signifikasi lebih kecil dari $\alpha$ = 5\%. Jadi, dapat disimpulkan bahwa H0 ditolak dan Ha tidak ditolak. Dan juga dari hasil t hirung lebih besar dari t tabel ( -3,177 > -,9797), maka Ha diterima, artinya asosiasi merek mempengaruhi intensi pembelian.

Kepribadian merek mempengaruhi intensi pembelian terhadap produk TOP coffe pada warga tanjung duren di Jakarta. Hasil uji-t antara X3 (kepribadian merek) dengan Y (intensi pembelian) menunjukkan tingkat signifikasi 0,004. Hal ini berarti kepribadian merek mempengaruhi intensi pembelian karena angka probabilitas / signifikasi lebih kecil dari $\alpha=5 \%$. Jadi, dapat disimpulkan bahwa H0 ditolak dan Ha diterima. Dan juga dari hasil t hitung lebih besar dari t tabel ( 2,896> 1,9797), maka Ha tidak ditotak, artinya kepribadian merek mempengaruhi intensi pembelian.

Karakteristik produk mempengaruhi intensi pembelian terhadap produk TOP coffe pada warga tanjung duren di Jakarta. Hasil uji-t antara X4 (karakteristik produk) dengan Y (intensi pembelian) menunjukkan tingkat signifikasi 0,000. Hal ini berarti asosiasi merek mempengaruhi intensi pembelian karena angka probabilitas / signifikasi lebih kecil dari $\alpha$ $=5 \%$. Jadi, dapat disimpulkan bahwa H0 ditolak dan Ha diterima. Dan juga dari hasil $\mathrm{t}$ hitung lebih besar dari t tabel ( 7,719> 1,9797), maka Ha tidak ditotak, artinya karakteristik produk mempengaruhi intensi pembelian.

Secara keseluruhan seluruh variabel independen selebriti endorser, asosiasi merek, kepribadian merek dan karakteristik produk mempengaruhi intensi pembelian terhadap produk TOP coffe pada warga tanjung duren di Jakarta. Nilai F dengan df (4 - $1=3)$; (125 - $4=121)$ adalah sekitar 2,7.Karena F hitung lebih besar dari F dari pada F tabel (23,339 > 2,7), maka H0 ditolak, artinya paling sedikut ada satu variabel independen yang mempengaruhi variabel intense pembelian.

\section{DAFTAR RUJUKAN}

Aaker D.A., (1991) Managing Brand Equity: Capitalizing on the Value of a Brand Name, Toronto: Maxwell Macmillan.

Aaker, Jennifer L. (1997) "Dimensions of Brand Personality”. Journal of Marketing Research, 34(8), 347 - 356. 
Adrian, Payne. (2000) Service Marketing Pemasaran Jasa. Yogyakarta: Andi.

Ajzen, I., \&Fishbein, M. (2005) The influence of attitudes on behavior. In D. Albarracin, B. T. Johnson, \&M. P. Zanna (Eds.), The handbook of attitudes (pp. 173-221). Mahwah, NJ: Erlbaum.

Anoraga, Pandji. (2000) Manajemen Bisnis . Jakarta: PT. Rineka Cipta.

Aritonang, R. Lerbin, R. (2007) Teori dan Praktik Riset Pemasaran. Bogor: Ghalia Indonesia.

Aritonang R., Lerbin R. (2009) Peramalan Bisnis, edisi kedua. Jakarta: Ghalia Indonesia.

Bansal, H. S., Taylor S.F. \& St. James, Y. (2005) "Migrating to New Service Providers: Toward a Unifying Framework of Consumers' Switching Behaviors”. Journal of the Academy of Marketing Science, 33 (1), 96- 115.

Bauer, H., Mader, R., \&Keller; T. (2001) An Investigation of The Brand Personality Scale. http.//marketing.byu.edu/ams/beuer-maderkeller. htm.

Belch, G. E. Dan Belch, M. A. (2007) Advertising and Promotion An Integrated Marketing Communications Perspective. (7th ed.). New York: McGraw hill Companies, inc.

Bruno Hasson. (2008) Fashion Branding : 7 Jurus Sukses Branding Bisnis MLM Fashion. Jakarta: Gramedia.

Chasanah, Uswatun., (2003) Kajian Bisnis "Membangun Ekuitas merek Melalui Brand Personality".Yogyakarta: STIE Widya Wiwaha.

Churchill, Gilbert A. (2005) Dasar-Dasar Riset Pemasaran, Edisi 4, Jilid I, Alih Bahasa Oleh Andriani, Dkk, Jakarta: Penerbit Erlangga.

Durianto, D., Sugiarto dan T Sitinjak (2001) Strategi Menaklukkan Pasar Melalui Riset Ekuitas dan Perilaku Merek, Jakarta: PT Gramedia Pustaka Utama.

Engel, James F., Blackwell, R. D., \&Miniard, P. W. (1990) Consumer Behavior. (6th ed.). International Edition, Forth Worth: The Dryden Press.

Engel, James F, et.al.. (1995) Consumen Behavior.Alih Bahasa: Budiyanto, Jilid 1 dan 2. Jakarta: Bina Rupa Aksara.

Ghozali, I. (2006) Aplikasi Analisis Multivariat dengan Program SPSS. Cetakan ke IV. Badan Penerbit Universitas Diponegoro. Semarang.

Kasali, Renald. (1992) Manajemen periklanan, konsep dan implikasinya di Indonesia.Jakarta: PT. Pustaka utama grafiti.

Kasali, Renald. (1998) Membidik pasar indonesia: segmantasi, targeting, positioning.Jakarta: PT. Pustaka utama grafiti.

Keller, K.L. (2003) Strategic Brand Management: Building, Measuring, and Managing Brand Equity, 2th ed., New Jersey: Prentice Hall.

Kertajaya, Herman. (2005) Mempertahankan Pelanggan Loyal. www.bisnisindonesia.com.

Kotler, Philip. (2005) Manajemen Pemasaran, Jilid 1, Edisi sebelas. Klaten: PT. Indeks Kelompok Gramedia.

Kotier, Philip \&Keller, K.L. (2006) Marketing Management. (12th ed.). New Jearsey: Person Prentice Hall.

Kountur, Ronny (2007) Metode Penelitian. Jakarta: PPM.

Low, G.S. and C.W. Lamb Jr (2000) "The Measurement and Dimensionality of Brand Association," Journal of Product \&Brand Management, 9 (6): 350- 368.

Maholtra, Naresh K. (1999) Marketing Research: An Applied Orientation.(3rd ed.). New Jersey: Prentice Hall, Inc. 
Maholtra, Naresh K. (2004) Marketing Research. New Jersey: pearson Prentice hall.

Mowen, john c. Dan michael minor. (2002) Perilaku konsumen (alih bahasa lina salim), jilid 1, edisi 5.jakarta: Erlangga.

Peter, P.L., \&Olson, C.J. (2002) Consumer Behaviour and Marketing Strategy (6th edition), America: The McGraw-Hill Companies.

Rangkuti, Freddy. (2004) The Power of Brand: Teknik Mengelola Brand Equity dan Strategi Pengembangan Merek dan Analisis Kasus dengan SPSS. Cetakan Kedua. Jakarta: Gramedia Pustaka Utama.

Royan, Frans M. (2004) Marketing Selebrities. Jakarta: PT Elex Media Komputindo.

Santoso, Singgih. (2005) Menguasai Statistik di Era Informasi Dengan SPSS 12. Jakarta: PT. Alex Media Komputindo.

Septyanto, Dihin. (2008). Pengukuran Variabel Dalam Penelitian, Univ.Ind. Esa Unggul.

Setiaji, Bambang. (2004). Panduan Riset dengan Pendekatan kuantitatif. Surakarta: Program Pascasarjana UMS.

Shimp, Terence A. (2003) Periklanan Promosi Aspek Tambahan Komunikasi Pemasaran Terpadu. Jakarta: Erlangga.

Shimp, terence A. (2007) Integrated Marketing Communication In Advertising and Promotion. (7th ed.) New York: McGraw hill Companies, inc.

Simamora, Bilson. (2008) Panduan Riset Perilaku Konsumen. Jakarta: PT. Gramedia Pustaka Utama.

Singarimbun, Masri. (1991) Metode PenelitianSurvezJakarta: LP3ES.

Solomon, M.R. (2007) Consumer Behavior Buying, Havingg and Being. (7th ed.). New Jersey: Person Prentice Hall.

Sugiyono (2003) Metode Penelitian Bisnis, cetakan kelima. Bandung: CV. AlfaBeta.

Sujianto, Agus Eko. (2007) Aplikasi Statistik dengan SPSS Untuk Pemula. Jakarta: Prestasi Pustaka.

Supphellen, M. (2000) "Understanding Core Brand Equity: Guideliness for in- depth Elicitation of Brand Associations," International Journal of Market Research,42 (3): 319-331

Supranto. J. (2003). Metode Riset: Aplikasinya dalam Pemasaran, Edisi ketujuh, Jakarta : Lembaga Penerbit Fakultas Universitas Indonesia.

Suyanto, M. (2005) Strategi Perancangan Iklan televisi Perusahaan Top Dunia. Yogyakarta: Andi.

Tjiptono, Fandy. (1997) Strategi pemasaran, edisi 1. Yogyakarta: Andi.

Tjiptono, Fandy, Candra, Yanto, \&Diana, Anastasia, (2004),Marketing Scales,Andi Ofset, Ed. 1, Yogyakarta

Washburn, J.H., B.D. Till and R. Priluck (2000) "Co-Branding: Brand Equity and Trial Effects”, Journal of Consumer Marketing,17 (7): 591-604. 